\title{
RANCANG BANGUN ENSIKLOPEDIA TANAMAN OBAT KALIMANTAN TENGAH BERBASIS ANDROID
}

\author{
Ferdiyani Haris $^{1)}$ dan Sherly Jayanti ${ }^{2)}$ \\ ${ }^{1}$ Sistem Informasi, STMIK Palangkaraya \\ ${ }^{2}$ Manajemen Informastika, STMIK Palangkaraya \\ ${ }^{1,2}$ Jl. G. Obos No. 114 Palangkaraya, 73112 \\ E-mail : sabila006@gmail.com ${ }^{1)}$, sherlyjayanti85@gmail.com ${ }^{2)}$
}

\begin{abstract}
ABSTRAK
Provinsi Kalimantan Tengah dengan luas wilayah 15,4 juta ha memiliki banyak sekali jenis tanaman yang dapat dimanfaatkan sebagai bahan obat-obatan. Dan masih ada sebagian masyarakat Kalimantan Tengah yang belum mengetahui jenis dan manfaat tanaman yang berpotensi obat tersebut. Walaupun sebagian informasi tersebut sudah bisa didapatkan melalui berbagai media baik cetak maupun daring, tetapi hal tersebut masih belum efektif dan efesien karena perlu waktu dan biaya. Dengan bantuan teknologi mobile yang sangat populer saat ini yaitu Android dapat dibangun suatu sistem ensiklopedia tentang jenis-jenis tanaman apa saja khususnya didaerah Kalimantan Tengah yang dapat dimanfaatkan sebagai bahan baku obat-obatan. Metode penelitian yang digunakan adalah penelitian dan pengembangan karena bertujuan menghasilkan dan menguji efektifitas sistem yang dibangun. Penelitian ini mengadopsi permodelan pengembangan perangkat lunak Prototipe yang terdiri dari 3 tahapan yaitu identifikasi dan analisa data, perancangan dan pembuatan prototipe serta pengujian dan perbaikan prototipe sehingga sesuai dengan kebutuhan sistem keseluruhan. Penelitian ini akan menghasilkan sistem yang dapat dimanfaatkan untuk menambah wawasan, pengetahuan dan panduan masyarakat dalam memanfaatkan beragam jenis tanaman khas Kalimantan Tengah untuk pengobatan berbagai macam penyakit
\end{abstract}

\section{Kata Kunci : Tanaman Khas Kalimantan Tengah, Android, Ensiklopedia, Penelitian dan Pengembangan, Prototipe}

\section{PENDAHULUAN}

Di Kalimantan Tengah terdapat sejumlah tanaman hutan yang sudah diidentifikasi berpotensi sebagai bahan obat yang biasa dimanfaatkan oleh masyarakat dan sebagian sudah diteliti. Tanaman yang berpotensi obat tersebut antara lain sangeh, lali, tuntung uhat, tambuhusan, katatupak atau katatiroi, kalakai, paku bukit, suli, raja mandak, lagundi, senggani, langise, muhur, kenyem, upak gemur, uru sambelum, bajakah kalalawit, kalapimping, tatupak, dadap, teken perei, kalapap, kayu mahamen dan masih banyak lagi. Sebagian masyarakat Kalimantan Tengah pun masih belum mengetahui jenis dan manfaat tanaman yang berpotensi obat tersebut.

Untuk mencari informasi tentang tanaman obat tersebut bisa melalui media buku ataupun internet. Akan tetapi media tersebut masih dianggap belum efektif dan efesien karena memerlukan biaya dan waktu yang cukup banyak termasuk media internet yang tidak semua masyarakat bisa menggunakannya. Seiring perkembangan teknologi yang begitu pesat saat ini terutama penggunaan teknologi mobile berbasis android di berbagai bidang tidak terkecuali bidang kesehatan termasuk hal yang berhubungan dengan obat-obatan medis baik herbal maupun non herbal, maka tentunya akan sangat membantu masyarakat apabila ada suatu sistem ensiklopedia mobile tentang jenis-jenis tanaman apa saja khususnya didaerah Kalimantan Tengah yang dapat dimanfaatkan sebagai bahan ramuan obat berbasis android tersebut.
Penelitian mengenai aplikasi ensiklopedia tanaman obat berbasis semantik web pernah dilakukan untuk menghasilkan sebuah aplikasi ensiklopedia tanaman obat dengan mempresentasikan model pengetahuan suatu domain, yaitu tanaman obat (Pradana dkk, 2016).

Penelitian yang dilakukan tentang media informasi tanaman obat dan penggunaannya sebagai sarana media pembelajaran bagi masyarakat untuk mendalami lebih detil tentang tanaman obat. Media informasi yang dihasilkan berbasis Desktop dan Web (Bitjoli dkk, 2017).

Selanjutnya penelitian tentang ensiklopedia kesehatan berbasis android pernah dilakukan guna memberikan pengetahuan tentang beragam istilah kesehatan bagi masyarakat umum (Haris, 2018).

Sistem yang dibangun pada penelitian ini akan memanfaatkan kemajuan teknologi mobile yang perkembangannya sangat pesat saat ini yaitu android. Sistem ini nantinya juga akan makin memperluas pengetahuan masyarakat khususnya Kalimantan Tengah tentang jenis-jenis tanaman khas endemik yang ada di provinsi Kalimantan Tengah dan dapat digunakan sebagai bahan obat-obatan. Atas dasar pemikiran tersebut, maka penulis akan melakukan penelitian untuk merancang dan membangun sistem ensiklopedia tanaman obat khas Kalimantan Tengah berbasis android.

\section{RUANG LINGKUP}

Dalam penelitian ini permasalahan mencakup:

1. Sistem yang dibangun berbasis Android. 
2. Ensiklopedia ini memuat informasi tentang obat tradisional Kalimantan Tengah yang terdiri dari 2 kategori yaitu :

1) Jenis tanaman, yang terdiri dari sub kategori :

1 Sub kategori pohon

2 Sub kategori semak/perdu

3 Sub kategori tanaman merambat/akarakaran

4 Sub kategori rumput dan tanaman pekarangan

5 Sub kategori paku-pakuan

6 Sub kategori parasit/epifit

2) Khasiat tanaman, terdiri dari sub kategori :

1 Sub kategori kecantikan dan problem kewanitaan

2 Sub kategori penyakit kulit

3 Sub kategori vitalitas pria

4 Sub kategori tumor dan kanker

5 Sub kategori kolesterol dan hipertensi

6 Sub kategori sakit perut, sakit gigi, malaria dan demam

3. Ensiklopedia ini akan menambah wawasan dan pengetahuan masyarakat khususnya Kalimantan Tengah tentang berbagai jenis tanaman khas Kalimantan Tengah yang dapat digunakan sebagai bahan baku obat.

\section{BAHAN DAN METODE}

Metode penelitian yang digunakan adalah research and development (Penelitian dan Pengembangan) karena sistem yang akan dikembangkan dan dihasilkan nanti dapat memiliki kualitas tinggi terutama informasi tentang jenis tanaman obat Kalimantan Tengah dan cara pemanfaatannya.

\subsection{Pengumpulan Data}

Pengumpulan data-data dilakukan dengan :

1. Pengamatan yaitu pengumpulan data dengan melakukan pengamatan langsung terhadap sampel data yang diperlukan.

2. Wawancara yaitu pengumpulan data dengan melakukan wawancara atau tanya jawab secara langsung.

3. Literatur yaitu pengumpulan data dengan melakukan studi pustaka mencakup buku-buku teks, jurnal, prosiding, artikel, diktat, makalah dan buku petunjuk teknis terpadu serta literatur lain baik berupa cetak maupun daring.

4. Pengumpulan data primer (data yang langsung dari sumbernya) dilakukan dengan cara pengamatan dan wawancara langsung terhadap pihak-pihak terkait yang dalam hal ini adalah Balai Pengkajian Teknologi Pertanian (BPTP) dan Dinas Pertanian Kalimantan Tengah

\subsection{Model Pengembangan Sistem}

Penelitian ini mengadopsi permodelan pengembangan perangkat lunak Prototipe. Adapun alur permodelan prototipe pada penelitian ini adalah sebagai berikut :
1. Listen to Customer
2. Build/Revise Mock-Up
3. Costumer Test Drives Mock-up

\subsection{Ensiklopedia}

Kata "Ensiklopedia" berasal dari bahasa Yunani enkyklios paideia yang bermakna karya referensi atau ringkasan yang menyediakan rangkuman informasi dari semua cabang pengetahuan atau dari bidang tertentu. Dalam kamus besar Bahasa Indonesia diartikan sebagai serangkaian buku yang menghimpun keterangan atau uraian tentang berbagai hal dalam bidang seni dan ilmu pengetahuan, yang disusun menurut abjad atau menurut lingkungan ilmu.

\subsection{Android}

Android merupakan sebuah sistem operasi perangkat mobile berbasis linux yang mencakup sistem operasi, middleware, dan aplikasi, serta merupakan platform terbuka (Open Source) bagi para pengembang (Programmer) untuk membuat aplikasi (Supardi, 2011).

Android adalah sebuah sistem operasi mobile yang berbasiskan pada versi modifikasi dari linux. Pertama kali sistem operasi ini dikembangkan oleh perusahaan Android.Inc. pada tahun 2005 Google membeli Android dan mengambil alih proses pengembangannya sekaligus team Developer Android. Android merupakan sebuah platform untuk perangkat mobile yang semakin populer, hal ini tidak lepas dari pengembangannya yang terbuka bagi para pembuat aplikasi. Google menginginkan android dirilis menjadi sebuah sistem operasi Open Source dan gratis, kebanyakan code android dirilis di bawah lisensi Open Source Apache yang berarti setiap orang bebas untuk menggunakan dan mengunduh source code Android secara penuh.

\section{PEMBAHASAN}

Berikut disajikan hasil implementasi dan penjabaran dari penelitian ini.

\subsection{Desain Sistem}

Penelitian ini menggunakan UML (Unified Modeling Language) sebagai permodelan sistem. Adapun UML (Unified Modeling Language) yang digunakan yaitu :

1. Diagram Use Case

Gambar 1 berikut merupakan diagram use case sistem yang dibangun : 


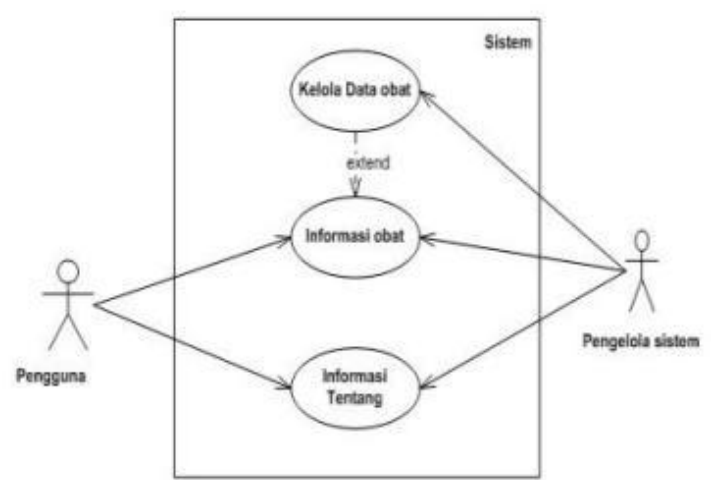

Gambar 1. Diagram Use Case

Pada sistem ini terdapat 2 (dua) aktor yaitu :

1) Pengguna

Merupakan setiap individu pengguna dari sistem Ensiklopedia ini

2) Pengelola

Merupakan individu pengelola/admin sistem Ensiklopedia ini

\section{Diagram Sequence}

Diagram Sequence merupakan diagram yang digunakan untuk menggambarkan interaksi antar objek dengan penekanan pada urutan proses atau kejadian, sebagaimana gambar 2 berikut :

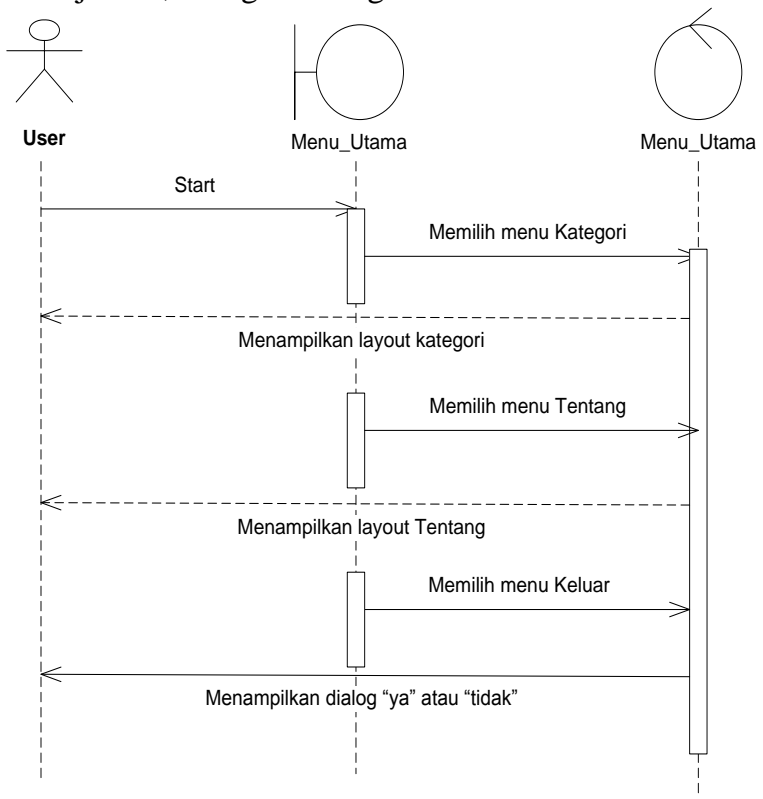

Gambar 2 . Diagram Sequence

\section{Diagram Activity}

Diagram Activity menggambarkan berbagai alur aktivitas dalam sistem yang sedang dirancang, bagaimana masing-masing alir berawal, decision yang mungkin terjadi, dan bagaimana akhir aktivitas. Gambar 3 memperlihatkan diagram activity sistem :

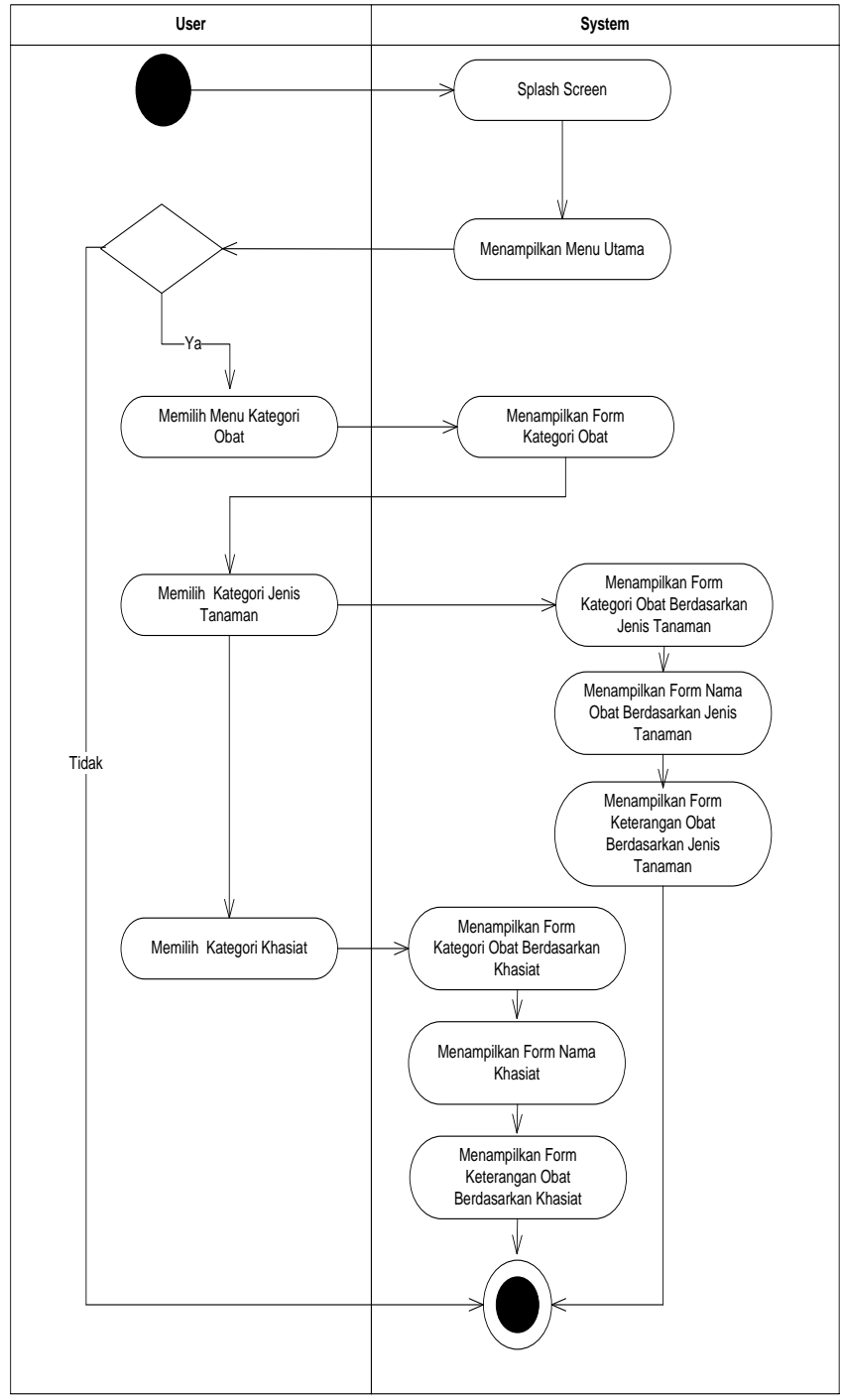

Gambar 3. Diagram Activity Menu Kategori Obat

\section{Diagram Class}

Diagram Class merupakan diagram yang digunakan untuk menggambarkan class, fitur, dan hubungan-hubungan yang terjadi. Pada diagram ini pendekatan berorientasi objek memegang peran yang sangat penting. 


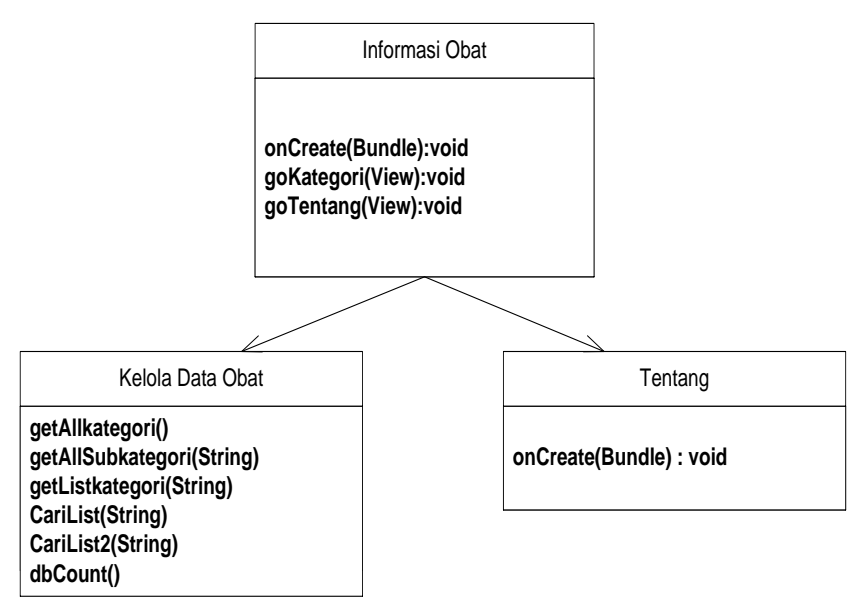

Gambar 4 . Class Diagram

\subsection{Implementasi}

Berikut implementasi dari penelitian ini

1. Splash Screen

Pada splash screen akan ditampilkan sebuah tampilan yang berisi berupa cover yang di dalamnya terdapat judul/ nama aplikasi dan gambar obat tradisional, terlihat pada gambar 5 :

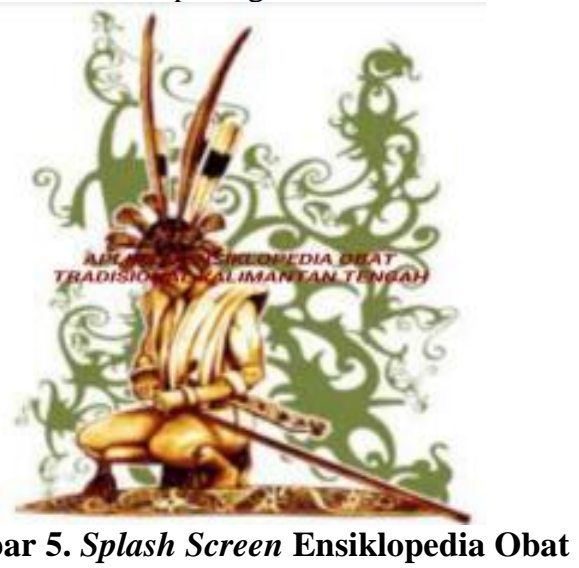

2. Menu Utama

Menu utama memiliki 3 menu pilihan yaitu : Kategori Obat, Tentang, dan Keluar. Gambar 6 memperlihatkan menu utama sistem :

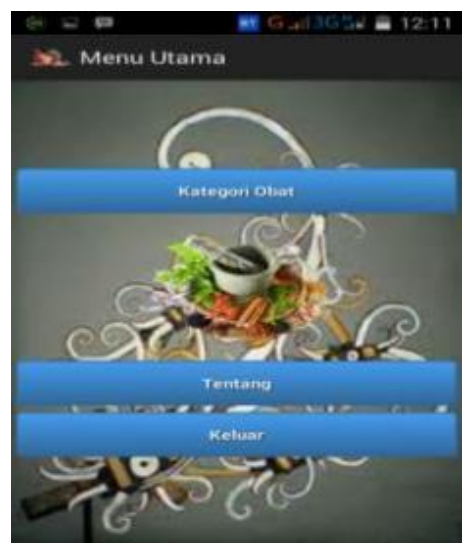

Gambar 6. Menu Utama Ensiklopedia Obat
3. Menu Kategori Obat

Menu pilihan Kategori Obat berfungsi untuk memilih informasi obat berdasarkan kategori jenis tanaman atau khasiat. Terlihat pada gambar 7 berikut :

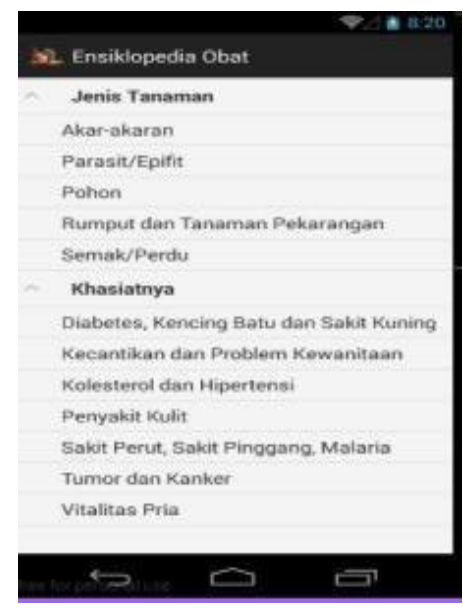

Gambar 7. Menu Kategori obat

Pada menu ini terdapat 2 submenu yaitu :

1) Submenu Jenis Tanaman

Submenu ini untuk memilih jenis obat berdasarkan kategori jenis tanaman. Sebagaimana gambar 8 berikut :

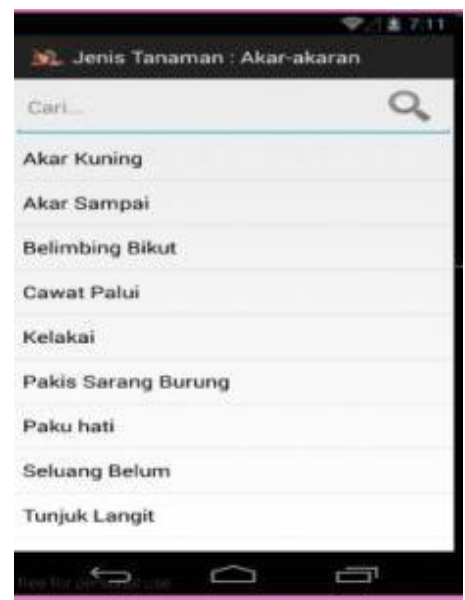

Gambar 8. Submenu Jenis tanaman

2) Submenu Khasiat

Submenu ini memberikan informasi tentang khasiat jenis tanaman dan cara pengolahannya menjadi obat. Seperti terlihat pada gambar 9 ini : 


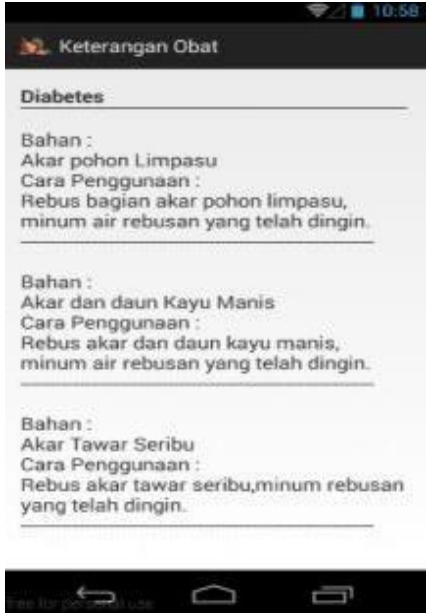

Gambar 9. Submenu Keterangan khasiat obat

4. $\quad$ Menu Tentang

Menu ini untuk menampilkan halaman tentang Ensiklopedia obat tradisional Kalimantan Tengah. Terlihat pada gambar 10 berikut :

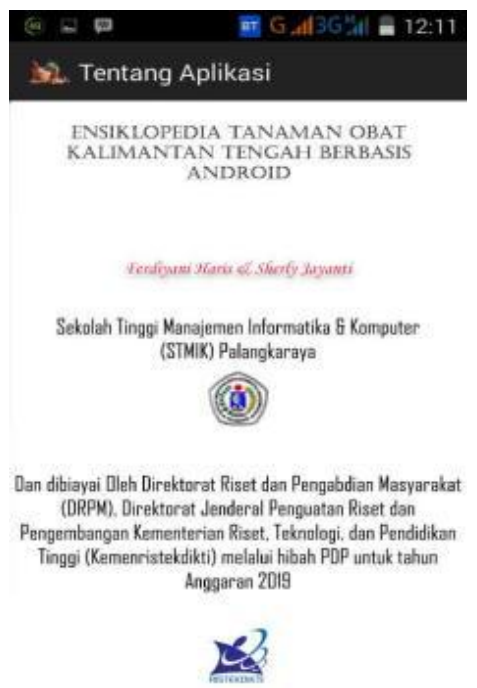

Gambar 10. Menu Tentang

\subsection{Pengujian}

Pengujian terhadap sistem dilakukan dengan black box testing bertujuan untuk menguji apakah komponenkomponen sudah dibuat sesuai dengan yang diharapkan. Berdasarkan hasil pengujian didapatkan kesesuaian hasil pengujian dengan yang diharapkan. Berikut tabel pengujian black box testing yang dilaksanakan :

Tabel 1. Pengujian Black Box Testing

\begin{tabular}{|l|l|l|l|}
\hline \multicolumn{1}{|c|}{ Kelas Uji } & \multicolumn{1}{|c|}{ Butir Uji } & \multicolumn{1}{|c|}{ Harapan } & Hasil \\
\hline Pengujian & Proses & Sistem dapat & Sesuai \\
Splash Screen & Tampil & menampilkan & \\
& form Splash & Splash Screen & \\
& Screen & & \\
\hline
\end{tabular}

\begin{tabular}{|c|c|c|c|}
\hline $\begin{array}{l}\text { Pengujian } \\
\text { Menu Utama } \\
\text { Ensiklopedia }\end{array}$ & $\begin{array}{l}\text { Proses } \\
\text { tampil menu } \\
\text { utama }\end{array}$ & $\begin{array}{l}\text { Menu Utama } \\
\text { dapat } \\
\text { ditampilkan }\end{array}$ & Sesuai \\
\hline $\begin{array}{l}\text { Pengujian } \\
\text { Menu } \\
\text { Kategori Obat }\end{array}$ & $\begin{array}{l}\text { Proses } \\
\text { tampil menu } \\
\text { kategori obat }\end{array}$ & $\begin{array}{l}\text { Menu kategori } \\
\text { obat dapat } \\
\text { ditampilkan }\end{array}$ & Sesuai \\
\hline $\begin{array}{l}\text { Pengujian } \\
\text { Submenu } \\
\text { Jenis } \\
\text { Tanaman }\end{array}$ & $\begin{array}{l}\text { Proses } \\
\text { tampil } \\
\text { submenu } \\
\text { jenis } \\
\text { tanaman } \\
\end{array}$ & $\begin{array}{l}\text { Submenu } \\
\text { Jenis tanaman } \\
\text { dapat } \\
\text { ditampilkan }\end{array}$ & Sesuai \\
\hline $\begin{array}{l}\text { Pengujian } \\
\text { Submenu } \\
\text { Khasiat Obat }\end{array}$ & $\begin{array}{l}\text { Proses } \\
\text { tampil } \\
\text { submenu } \\
\text { khasiat obat }\end{array}$ & $\begin{array}{l}\text { Submenu } \\
\text { khasiat obat } \\
\text { dapat } \\
\text { ditampilkan }\end{array}$ & Sesuai \\
\hline $\begin{array}{l}\text { Pengujian } \\
\text { Menu Tentang }\end{array}$ & $\begin{array}{l}\text { Proses } \\
\text { tampil menu } \\
\text { tentang }\end{array}$ & $\begin{array}{l}\text { Informasi } \\
\text { tentang sistem } \\
\text { ensiklopedia } \\
\text { dapat } \\
\text { ditampilkan }\end{array}$ & Sesuai \\
\hline
\end{tabular}

\section{KESIMPULAN}

Sistem Ensiklopedia Obat Tradisional Kalimantan Tengah Berbasis Android yang telah dibangun ini dapat membantu memudahkan pengguna khususnya masyarakat Kalimantan Tengah mencari informasi tentang obat tradisional Kalimantan Tengah disertai dengan panduan dalam pengolahannya

Berdasarkan ujicoba dengan menggunakan black box testing terhadap sistem didapatkan hasil yang Sesuai dengan yang diharapkan.

\section{SARAN}

Ensiklopedia ini dapat dikembangkan dengan menambahkan fitur update database secara online disertai dengan penambahan fitur multimedia dan animasi bergerak.

Dapat ditambahkan juga menu konsultasi dengan tenaga ahli pengobatan tradisional yang menggunakan berbagai jenis tanaman herbal sebagai bahan baku obat.

\section{DAFTAR PUSTAKA}

Apriani, Anita., Gufroni, Irham A., \& Mubarok, Husni., 2012. Rancang Bangun Aplikasi Sistem Pendukung Keputusan Pemilihan Altenatif Tanaman Obat Berbasis Web. Journal Universitas Siliwangi Tasikmalaya. Volume 1, Nomor 1 Tahun 2012. Tasikmalaya : Universitas Siliwangi.

Bitjoli, Rani C., Liliana, Purbowo, Anita N., 2017. Media Informasi Tanaman Obat dan Penggunaannya. Jurnal INFRA. Volume 5, Nomor 1 Tahun 2017. Surabaya : Universitas Kristen Petra.

Guritno, Suryo., Sudaryono., \& Raharja, Untung. 2011.

Theory and Application of IT Research. Yogyakarta : Andi Offset. 
Hakim, Ahmad R., Andrea, Reza., Antoni, Devian. Membangun Edugame " Baby Zoo Puzzle" Berbasis Android Dengan Game Agent Implementasi Finite State Machine. Jurnal Sebatik. Volume 16, Nomor 1 Tahun 2016. ISSN : 14103737. Samarinda : STMIK Widya Cipta Dharma.

Haris, Ferdiyani. 2018. Rancang Bangun Aplikasi Ensiklopedia Kesehatan Berbasis Android. Jurnal Sains Komputer dan Teknologi Informasi. Volume 1, Nomor 1 Tahun 2018. ISSN : 2655-7460. Palangkaraya : Universitas Muhammadiyah Palangkaraya.

Haris, Ferdiyani., Ningsih, Tri Kurnia. 2017. Aplikasi Pengenalan Seni Kerajinan Tangan Masyarakat Dayak Provinsi Kalimantan Tengah Berbasis Android. Jurnal SAINTEKOM. Volume 7, Nomor 2 Tahun 2017. ISSN : 2503-3247. Palangkaraya : STMIK Palangkaraya.

Munadi, Ernawati dan Salim, Zamroni., 2017. Info Komoditi Tanaman Obat. Jakarta : Badan Pengkajian dan Pengembangan Perdagangan Kementerian Perdagangan Republik Indonesia.

Pradana, Febri., Jusak, Adrian, Ignatius., 2016. Rancang Bangun Aplikasi Ensiklopedia Tanaman Obat Berbasis Semantik Web. Jurnal JSIKA. Volume 5, Nomor 8 Tahun 2016. ISSN : 2338-137X. Surabaya : STMIK STIKOM.

Pressman, Roger, 2012, Rekayasa Perangkat Lunak Pendekatan Praktisi (Buku Satu Edisi 7), Yogyakarta : Andi Offset.

Supardi. 2011. Semua Bisa Menjadi Programer AndroidBasic. Jakarta : Elex Media Komputindo.

Susiarti, Ratna A., 2017. Tanaman Sebagai Sumber Senyawa Bioaktif : Peranannya Dalam Terapi dan Pengembangan Obat Baru. Pengukuhan Guru Besar. Yogyakarta : Fakultas Farmasi UGM.

Wismarini, Th. Dwiati., Santoso, Dwi B., Untari Ningsih, Dewi H., 2012. Elektronik Ensiklopedia Tanaman Herbal Sebagai Bank Data Digital Tanaman Obat. Jurnal Teknologi Informasi Dinamik. Volume 17, Nomor 2 Tahun 2012. ISSN : 0854-9524. Semarang : Universitas Stikubank.

\section{UCAPAN TERIMA KASIH}

Terima Kasih kepada Direktorat Riset dan Pengabdian Masyarakat (DRPM), Direktorat Jenderal Penguatan Riset dan Pengembangan Kementerian Riset, Teknologi, dan Pendidikan Tinggi (Kemenristekdikti) yang telah membiayai penelitian ini melalui hibah PDP untuk tahun anggaran 2019. 